Article

\title{
Local Territorial Cohesion: Perception of Spatial Inequalities in Access to Public Services in Polish Case-Study Municipalities
}

\author{
Wirginia Aksztejn \\ Department of Local Development and Policy, Faculty of Geography and Regional Studies, University of Warsaw, \\ 00-927 Warsaw, Poland; E-Mail: wa.aksztejn@uw.edu.pl
}

Submitted: 15 June 2020 | Accepted: 18 September 2020 | Published: 3 December 2020

\begin{abstract}
The aim of this article is to investigate a research area situated off the mainstream of social inequality considerations: territorial inequalities at the local (municipality) level. The marginalisation of this aspect can be seen both in EU cohesion policies and in academic discourse. The European policies focus their attention (and funding) on the regional level, and researchers who study more local contexts tend to be interested in spatial inequalities in the urban environment with an emphasis on metropolises. This article downscales territorial inequalities to the level of municipalities that are varied in terms of size, location and function. The perspective I take on in the study concentrates on accessibility of selected public services such as public transportation and childcare within the locality, and the perception of spatial inequalities in the eyes of local actors from the public, civic and business sectors. The research indicates that a subjective view on local inequalities does not necessarily match the actual level of service provision. In the article I reflect on the reasons for this disparity and potential consequences for local policies and bridging the gaps.
\end{abstract}

\section{Keywords}

accessibility to public services; childcare; public transport; spatial inequalities; territorial cohesion

\section{Issue}

This article is part of the issue "Cohesion in the Local Context: Reconciling the Territorial, Economic and Social Dimensions," edited by Anja Jørgensen (Aalborg University, Denmark), Mia Arp Fallov (Aalborg University, Denmark), Rikke Skovgaard Nielsen (Aalborg University, Denmark), Hans Thor Andersen (Aalborg University, Denmark) and Maja de Neergaard (Aalborg University, Denmark).

(C) 2020 by the author; licensee Cogitatio (Lisbon, Portugal). This article is licensed under a Creative Commons Attribution 4.0 International License (CC BY).

\section{Introduction}

The objective of this article is to downscale the phenomenon of spatial inequalities and the concept of territorial cohesion to the level of municipalities and to investigate perceptions of intra-municipal differences. Territorial cohesion and inclusive growth are an important question in EU policies and discourse (see, e.g., European Commission, 2010; Treaty of Lisbon, 2007). However, it is regions that are the main focus of interest. The allocation of funds has been aimed at supporting development in NUTS2 and NUTS3 entities that lag behind the European average. Inequalities at a more local level are overlooked both in EU policies and in statistics. In the last decade, the European cohesion policy suc- ceeded in shrinking the distance in economic development between EU countries; however, the differences between regions are still on the rise (Bachtler, Martins, Wostner, \& Żuber, 2017). This seems to pose a serious problem for the Community for at least two reasons. First, according to spatial disequilibrium hypothesis the inequalities are likely to deepen due to path dependencies being triggered or exacerbated, encouraging agglomeration economies and thereby contributing to a backwash effect and the creation of growth poles (Kaldor, 1970; Krugman, 1991; Myrdal, 1957; Thirlwall, 2014). Furthermore, perceived inequality in wealth gives rise to euroscepticism and populist movements by undermining trust in the fairness of European policies (Dijkstra, Poelman, \& Rodríguez-Pose, 2020; OECD, 2019). 
Although equalisation between the regions is still cited as the chief challenge for the years to come, the subregional level has gained recognition as an important agent of the implementation of policies and execution of structural change. To embrace fast-moving technological, economic and social changes "[p]olicy packages need to be integrated and coordinated, delivered at a national, regional and local levels, while being adapted to the needs of different territories" (Bachtler et al., 2017, p. 1).

The first step in attaining this objective is obviously to understand territorial capital and inequalities at a more detailed level than the inter-or intra-regional. Cities became the primary object of these in-depth inquiries, which is noticeable in the analyses of international organisations and in scientific publications. The reporting of OECD pays attention to the problem of inequalities in urban environment, as big cities are claimed to be the most affected by socio-economic segregation (OECD, 2018a, 2018b). Furthermore, cities and urban areas are recognised as "some of the most appropriate 'units' or scales to measure and assess multi-dimensional inequality, as well as propose effective policy responses" (OECD, 2018b, p. 11), which strengthens the argument in favour of special interest in metropolises. Scientific investigation of intra-urban inequalities has a long tradition (Castels, 1977; Duncan \& Duncan, 1955; Harvey, 1973). Also, more contemporary research on spatial disparities has been focused on metropolitan areas (Glaeser, Resseger, \& Tobio, 2009; Musterd, Tammaru, van Ham, \& Marcińczak, 2016; van Kempen \& Murie, 2009). Inequalities in rural areas are usually studied from the point of view of the paradigm of centreperiphery cleavages, demonstrating the gap between levels of wealth in main urban centres and the countryside. I argue, however, that the micro-scale spatial inequalities within rural communities are also an important and at the same time markedly under-researched issue. Also, economic parameters such as income dominate as measures of inequalities. Accessibility of public services is a less common subject of investigation, with research focused on transport, education and health services. However, understanding of inequalities needs to go beyond the spatial distribution of wealth or economic growth. Territorial cohesion-understood as fair access to services of general interest (SeGIs)-inclines us to investigate disparities in distribution of public service facilities at a very local level, where inequalities are actually experienced. In the Polish literature we find examples of comprehensive research into sub-regional differences in access to SeGls: at inter-county (Komornicki \& Ciołek, 2017) or even inter-municipal level (Stanny, Rosner, \& Komorowski, 2018; Świątek, Czapiewski, \& Komornicki, 2013). The intra-municipal approach is, however, scarce and restricted mostly to metropolises. Thus, the article binds together two less popular strands of research. First, it shifts the attention from income inequalities to unequal access to SeGls. Second, it extends the field of interest from urban (metropolitan) municipalities to more diversified sample of municipalities in order to obtain more comprehensive insight into intra-municipal disparities. The focus of the research is on the perception of spatial inequalities in order to analyse local expectations, capacity to act and potential patterns of interventions.

The phenomenon of intra-municipal inequalities is studied using the example of Polish municipalities selected as case-study localities in the project "Inequality, Urbanization and Territorial Cohesion: Developing the European Social Model of Economic Growth and Democratic Capacity" (COHSMO). The choice of localities was guided by ESPON classification of metropolises (ESPON, 2007), national delimitations of functional urban areas (Śleszyński, 2013), functional classification of municipalities (Śleszyński \& Komornicki, 2016) and official statistics with the objective of identifying crossnationally comparable exemplifications of metropolitan, suburban and rural environments.

The article is intended to translate the notion of territorial cohesion-understood as fair access to SeGIs-into the micro-level of municipalities, and to go beyond the prevalent urban context. First, I analyse various meanings and storylines behind the concept of territorial cohesion in order to set the theoretical framework for the research into perception of spatial differences in access to selected public services delivered at the municipality level and the importance of spatial exclusion in the local agenda. Second, I describe the empirical approach: methods of analysis, case localities and data sources. Next, I present the results of the study based on qualitative interviews and a standardised questionnaire, and discuss the findings against the background of local organisational structures and strategic documents to assess the salience of intra-municipal inequalities. Finally, some conclusions are offered regarding local territorial cohesion in various settlement contexts.

\section{Theoretical Underpinnings}

As remarked by Dabinett (2011) territorial cohesion is a construct very much embedded in European policies and spatial planning, and difficult to find anywhere else. It is the third pillar of European 'cohesion agendas.' While the Maastricht Treaty (1992) already formulated postulates of economic and social cohesion of the European territory, the spatial aspect trickled in via the Treaty of Amsterdam (1997), the European Spatial Development Perspective (CEC, 1999) and the 2000 Lisbon Agenda (to be later explicitly addressed by the 2007 Leipzig Territorial Agenda and embraced in the Europe 2020 Strategy; see European Commission, 2010). The term itself is an interdisciplinary concept, encompassing economy, demography, political and urban studies. The ambiguity in which it entered the European debate has ever since troubled researchers, spatial planners and policy makers trying to figure out how to understand, operationalise and finally measure it. The attitudes towards the vague character of territorial cohesion vary 
from outright criticism to hopeful acceptance that the pluralism in how it is understood and implemented by Member States is an opportunity rather than a critical flaw. The opponents would put it under the label coined by Ann Markusen (1999), "fuzzy concepts, scanty evidence, policy distance," while others term it "a catalytic concept around which several (spatial and non-spatial) discourses and policy practices have been generated" (Servillo, 2010). However, simultaneously, a lot of effort has been made to resolve the disputed lack of clarity in terms of scope and indicators (Abrahams, 2014; Dao, Plagnat Cantoreggi, \& Rousseaux, 2017; CEC, 2008; ESPON, 2013; Faludi, 2004; Medeiros, 2016; Mirwaldt, Mcmaster, \& Bachtler, 2009)-shortcomings that hinder a coherent scientific approach. Scholars and practitioners put forward various methods of pinning down the elusive concept-and not merely by formulating definitions and measures. For example, Mirwaldt et al. (2009) proposed to define territorial cohesion by examining the suggested ways of achieving it and focused on related postulates of territorial cooperation and horizontal coordination. Meanwhile, van Well (2012) concludes that there are different storylines revolving around territorial cohesion present in EU documents and reports: normative storylines, ESPON storylines, the Territorial Agenda storylines, the Green Paper storylines, etc. By contrast, Abrahams (2014) - in the face of the multitude of often incompatible definitions and storylines-advocates a pragmatic rather than essentialist approach to understanding the concept: instead of asking what territorial cohesion is, he advises to assess what it does or might do.

From this variety of approaches to giving precision to the disputed notion, we can, however, derive some commonalities and recurrent themes. They pertain to two aspects of territorial cohesion: its objectives and the procedural means to achieve them. Faludi (2004) describes these two facets of territorial cohesion as the logic of regional development and the co-ordination of policies with an impact on one and the same territory.

As regards the objectives, at the heart of territorial cohesion is an attempt to counter the unyielding logic of economic growth and competitiveness in order to make room for polices aimed at reducing inequalities in their spatial dimension, social inclusion and sustainable development. Depending on the storyline or country's tradition, values or interest (Doucet, 2006; Mirwaldt et al., 2009) the emphasis can be laid on territorially balanced growth or spatial justice and fair distribution of life chances. The repeating postulates of territorial cohesion include: (i) polycentricity (CEC, 2008; Dabinett, 2011; Dao et al., 2017; Medeiros, 2016; Mirwaldt et al., 2009), (ii) balanced development (Dao et al., 2017; CEC, 2008; ESPON, 2013; Medeiros, 2016; Mirwaldt et al., 2009), (iii) accessibility of SeGIs (Böhme \& Gløersen, 2011; CEC, 2008; Dabinett, 2011; Dao et al., 2017; Mirwaldt et al., 2009) and (iv) connectivity between the centre and peripheries (Dabinett, 2011; Mirwaldt et al., 2009).
In terms of means of arriving at the desired outcomes, territorial cohesion's interpreters accentuate the need for territorial governance and coordination of policies (Dao et al., 2017; Faludi, 2004; Mirwaldt et al., 2009). The Green Paper on Territorial Cohesion (2008) and the Barca Report (Barca, 2009) lay the emphasis on the strength of the local context. Place-informed policies and place-based interventions gained recognition as 'territorial keys' (Böhme, Doucet, Komornicki, Zaucha, \& Swiatek, 2011) to unleashing growth potential. Also, in the face of neoliberal policies resulting from state rescaling (Brenner, 2009) local communities are perceived as a resistance factor that brings a socio-spatial dimension to the political agenda. Thus, multi-level governance including both vertical and horizontal collaboration constitutes a vehicle for achieving objectives of cohesion policy.

This article takes as a point of departure the 'spatial justice' strand of territorial cohesion, which states that "people should neither be advantaged nor disadvantaged because they happen to reside within the boundaries of a particular locality" (Dabinett, 2011, p. 2). The focus is on the provision of public services considered to be SeGIs, whose importance for social cohesion is recognised in the European Model of Society. I decided to investigate the accessibility of services at a local level, where their deficiency is actually experienced and can result in unequal opportunities and life chances.

Guided by the focus of the research (i.e., the microlevel) I take special interest in selected SeGIs from among those that are at least partially under municipal jurisdiction in Poland: childcare services (nurseries and kindergartens) and public transportation. Simultaneously, the chosen services play an important role in equalisation of life chances. The provision of institutionalised childcare supports the Social Investment Strategy (Morel, Palier, \& Palme, 2012) - an approach that seeks to provide social and economic wellbeing by increasing participation in the labour market. It perceives some welfare state policies as long-term investments in human capital-a stock that facilitates attaining high-quality jobs and provides resilience in the face of social risks. Childcare services specifically not only reinforce cognitive development and early education, but they also enable re-entrance into the labour market (especially for women) and the reconciliation of family life and a professional career. In this context, access to public services can be considered not only equality of opportunity and conditions, but also of outcome (Turner, 1986). Public transportation, on the other hand, is responsible for connectivity and accessibility of services, especially second-tier ones. It is vital for providing better education and job opportunities. The European Commission promotes multi-mode transport and accentuates the need to restrict the use of conventional private transport to the "final miles" of the journey or stretches where providing collective transport is costly (CEC, 2011). However, we need to be aware that individual means of transport, even over short distances, may not be an option for members of a number of vulnerable 
groups: the young, seniors or the poor. Analyses cited by Komornicki (2019) illustrate the gap between the number of healthcare facilities and secondary schools accessible within 30 minutes by car as opposed to by public transport. The allocation of public transport to the specific tier of local government in Poland is not very straightforward, though. City public transport is the clear responsibility of the municipal government. Regional railway transport is under regional government jurisdiction. But local and subregional bus services are not clearly allocated to any of the tiers, and in practice both municipal and county governments play a role in organising this service. In general, bus services are to a large extent deregulated in Poland, and provided in insufficient quality and quantity. Several experts call for a more active role of local governments.

Following Servillo's (2010) observation that research into territorial cohesion involves defining policy principles, territorial dimension (scale), strategic policy options and territorial governance, I ask the following research questions:

1. How is access to SeGls assessed in different settlement contexts (urban, suburban and rural). Is the subjective view reflected in more objective measures?

2. Is accessibility of SeGls viewed as an important local issue?

3. Is territoriality, and in particular spatial disparities in access to SeGls, a salient theme of the local agenda?

The research explores perception of inequalities, treating it as a precondition for intervention. The mere existence of disparities is not enough to take action against them. As demonstrated in previous studies the presence of differences concerning life situation (e.g., income or access to societal goods) can be tolerated if these are based on a socially accepted explanatory factor (Han, Janmaat, Hoskins, \& Green, 2012); otherwise, the sense of breach of justice norms (Domański, 2013) or deviation from a desired model of social development incites social tension and/or political reaction. Thus, the reasons for deeming spatial inequalities tolerable can lie both in objectively existing circumstances $(\mathrm{H} 1)$ and in subjective expectations and aspirations $(\mathrm{H} 2)$.

The place-related hypothesis says:

$\mathrm{H} 1$ : The more difficult it is to equalise access to public services due to factors or circumstances considered objective hindrances, the greater the acceptance of spatial inequality regardless of the actual level of service provision.

The expectations-related hypothesis claims:

$\mathrm{H} 2$ : Past experiences, habits and expectations shape the level of acceptance of spatial inequalities. They can work either way-either increasing or decreasing tolerance, regardless of current circumstances.

The selected localities, which vary in general level and territorial distribution of public services provision, provide diversified contexts for testing the hypotheses. $\mathrm{H} 1$ suggests that in sparsely populated rural areas local actors are more lenient with regard to spatial inequalities and give them lower priority on the local agenda. On the other hand, $\mathrm{H} 2$ claims that people's expectations matter most in the perception of spatial disparities. Those accustomed to accessibility of public services (from urban and suburban localities) will be more demanding and more critical of the current level of service provision. These two effects predicted by $\mathrm{H} 1$ and $\mathrm{H} 2$ can strengthen one another or be in opposition. From the perspective of cohesion policy and territorial governance it is also interesting to investigate who is more aspirational: local politicians or local communities?

\section{Empirical Strategy}

\subsection{Research Method}

The study represents a mixed-methods research strategy (Venkatesh, Brown, \& Sullivan, 2016). The analysis of the selected case studies was based on a combination of methods including (1) desk research and analysis of available official statistics, (2) analysis of local development strategies, (3) in-depth interviews with local actors based on a semi-structured research scenario, and (4) a standardised questionnaire administered at the end of the interview aiming to summarise the respondent's opinion on spatial inequalities. This article focuses on the results of the survey, but it utilises findings of the remaining techniques to provide the context for analyses and enable better understanding of the collected data.

Official statistics were used to describe the investigated localities and illuminate the general level of public services provision and their territorial distribution in each of the municipalities. The data used for comparisons between the case-study locations at LAU-2 level was acquired from Statistics Poland [Główny Urzq̨d Statystyczny] and Local Data Bank. The availability of data at sub-municipal level is generally very limited, whereas it is vital to access the differentiation of the access to public services. This difficulty was partly resolved with the means of desk research covering the websites and strategic documents of the investigated municipalities and some ad-hoc external reports (Komornicki, 2019; Stanny et al., 2018).

The recruitment for in-depth interviews was guided by the objective to investigate the local development from the perspective of territorial cohesion and to explore the intensity and forms of cooperation between public and private sectors. Therefore, the sample consisted of: 
1. Public actors: local politicians (mayors, councillors), local officials (from departments responsible for local development, provision of public services or social care).

2. Community actors: representatives of nongovernmental organisations (involved in supporting local development, counteracting social exclusion or providing public services) and local communities (village heads, members of village councils). Their opinions were treated as the closest approximation of the voice of the citizens.

3. Business actors: local entrepreneurs and representatives of local business associations.

It is important to accentuate that the respondents were local leaders and activists. This of course introduces a specific context into the analysis. First of all, interviewees had above-average knowledge about local policies and the socio-economic situation of the municipality. They were able to formulate more general, fact-based opinions. On the other hand, their everyday life experience and attitudes as representatives of the local elite may not fully reflect those of ordinary members of the local community, not to mention the socially or spatially excluded. However, taking into consideration the objectives of the study, the interviewees provided the desired insight into the mindset of influential local stakeholders who tend to dominate local discourse and formulated policies (Swyngedouw, 2005).

In each locality there were at least 20 interviews. Table 1 provides details of sample size and structure.

\subsection{Selected Localities}

The case-study localities represent three different settlement types: urban (metropolitan), suburban and rural, all situated in one Polish region-Pomerania. In terms of structures of territorial organisation, the localities were defined as municipalities (LAU-2 entities) in order to com- bine the local-level character with the political scale responsible for the provision of the public services under investigation. Otherwise the case localities exemplify very different environments in terms of size, population density, function and economic standing. The objective was to select localities that provided an illustration of typical urbanisation-related phenomena (urban migration, suburbanisation, depopulation of rural areas) and could reveal issues connected with territorial cohesion at different scales. The key dimensions were function and location in settlement grid, prevalent demographic trends and, consequently, condition of the local economy (affluence, labour market situation, etc.). Table 2 provides basic background data concerning the size, distance to local and regional centres, and economic standing. In addition, the selected localities were expected to be internally diversified, in order to provide the opportunity to investigate intra-municipal inequalities.

Gdańsk (the urban case) is the sixth-largest city in Poland population-wise, the capital of Pomerania Region and the core city of so called Tricity agglomeration, with administrative powers combining municipal (LAU-2) and county level (LAU-1). Having territorial assets in abundance-from environmental, through economic to cultural and anthropic capital (Servillo, Atkinson, \& Russo, 2012)-Gdańsk drives the local and regional development. Despite suburbanisation processes in the neighbouring municipalities, the city's population has been growing steadily. Urban plans lay emphasis on 'inner growth' and 'controlled sprawl.' However, dynamic development of the city's southern and south-western outskirts has posed a challenge for the provision of infrastructure and SeGIs. In this study Gdańsk exemplifies a vibrant, affluent metropolis, aspiring to providing good quality of life while making the best of its economic potential.

Pruszcz Gdański-the suburban case-is a compound entity representing high-density settlement in the north-western part adjacent to Gdańsk and the sparsely

Table 1. Size and structure of the sample.

\begin{tabular}{lccr}
\hline & Urban & Suburban & Rural \\
\hline Public actors & 12 & 11 & 11 \\
Community actors & 7 & 7 & 5 \\
Business actors & 5 & 5 & 5 \\
In total & $\mathbf{2 4}$ & $\mathbf{2 3}$ & $\mathbf{2 1}$ \\
\hline
\end{tabular}

Table 2. Basic background data on case localities.

\begin{tabular}{lccccc}
\hline & $\begin{array}{c}\text { Population } 2018 \\
(\downarrow \uparrow-\text { trend in } \\
10 \text { years })\end{array}$ & $\begin{array}{c}\text { Area } \\
\left(\mathrm{km}^{2}\right)\end{array}$ & $\begin{array}{c}\text { Distance to county's/region's } \\
\text { capital }(\mathrm{km})\end{array}$ & $\begin{array}{c}\text { Revenues from PIT per } \\
\text { tax-payer 2016 (euro) }\end{array}$ & $\begin{array}{c}\text { Unemployment } \\
\text { rate 2018 (\%) }\end{array}$ \\
\hline Urban & $466631 \uparrow$ & 262 & $0 / 0$ & 7813 & 2,9 \\
Suburban & $61110 \uparrow$ & 160 & $0 / 10$ & 7812 & 2,8 \\
Rural & $9078 \downarrow$ & 224 & $20 / 160$ & 4272 & 10,5 \\
\hline
\end{tabular}


populated, rural area in the estuary of the Vistula River. Its location within the Tricity agglomeration is its greatest territorial asset impacting its economic and demographic development. Beneficially situated next to Gdańsk and transportation corridors, the locality is a particularly attractive location for logistics companies and distribution centres. Due to suburbanisation processes its population has increased by $33 \%$ in the last decade. In this study Pruszcz Gdański represents a suburban locality owing its economic success to its mighty neighbour, and coping with the demographic consequences. The dual character of the suburban case-comprised of both urbanised and rural areas-provides the opportunity to analyse attitudes and policy responses to spatial inequalities in two very different territorial settings.

Debrzno-the rural case-encapsulates characteristics of inner peripheries: remotely located at the junction of three regions, it is facing infrastructure deficiencies, demographic decline and economic difficulties. Its economic and social situation were dramatically aggravated in the nineties as a result of the post-communist transformation that swept away its economic pillars: stateowned farms and the garrison (the unemployment rate peaked at $37 \%$ ). Without its main employers and social care providers, the community had to find its way in the new socio-economic reality. Although the situation has improved thanks to a local development plan prepared and implemented with substantial participation of the Third Sector and financed with external (mainly EU) funds, the municipality is still troubled with out-migration, long-term unemployment and uncertain bases of its further growth. In the study, Debrzno illuminates the problem of spatial inequalities in remote, rural areas with weak economic potential. In terms of population distribution, approximately $60 \%$ of its residents dwell in the central town and the rest are dispersed in the surrounding villages that vary in size (population from 50 to 700 people), affluence (post stateowned farms vs. villages of wealthy farmers and orchard owners) and accessibility (situated along main roads vs. devoid of paved roads).

\subsection{Selected Policy Areas}

In the study, territorial cohesion was operationalised as access to SeGIs. In the empirical part, the term 'spatial inequalities' was translated into more natural language as "unequal access to public services (such as public transportation, childcare and education facilities) for inhabitants from different parts of municipality/city." In the questionnaire, respondents were asked to assess local accessibility of public services in general. During in-depth interviews, public transport and childcare were explored in more detail-through a map-aided exercise aimed at identifying excluded areas and consequences of territorial inequalities.

Grey literature research was focused on the significance attributed to childcare and public transport provision in strategic documents. Special attention was also paid to territorialisation of local policies: do policymakers treat their municipality as a point on the map-as a homogeneous entity-or are they sensitive to its internal diversification and specific needs of different parts of the locality?

\section{Results}

\subsection{Statistics and Grey Literature}

Before analysing the results of the survey it is important to provide a brief socio-historical introduction to public service provision in Poland, which impacts the present status quo. In 1989 Poland underwent a political and economic transition-from an authoritarian state with a centrally planned economy to a democratic, free-market country. Along with economic shock the transition was accompanied by a reorganisation of public services provision. Local governments and the private sector took over SeGls such as childcare and public transportation. In the nineties this resulted in a significant decrease in service coverage, especially in rural areas: the number of kindergartens dropped by $38 \%$ and preschool enrolment among children aged 3-5 decreased from $17.8 \%$ to $15.7 \%$ (Levitas \& Herczyński, 2002). Whereas availability and accessibility of childcare improved with time, the transition marked the beginning of a more enduring collapse in public transport outside functional urban areas. Having said that, it is necessary to emphasise that, before 1989, provision of public services-although motivated by the ideal of equalisation of access-was troubled by numerous malfunctions and deficiencies of the system. Resourceful solutions that bypassed the absurdities of central planning by seeking community-or family-based alternatives to the inefficient state-offered solutions were a common experience for the society of the time.

The investigated localities differ in terms of general level of provision and intra-municipal accessibility of SeGls. The urban locality offers a dense bus and tram network, Rapid Municipal Train and Metropolitan Train, which provide connectivity within the agglomeration. In Gdańsk alone there are 4.5 public transport stops per square kilometre. The coverage of children in childcare is $13 \%$ for $0-2$-year-olds and $92 \%$ for 3-5-year-olds (which is above the national average). Mostly newly constructed residential areas on the outskirts of the city suffer from under-developed networks of public services. In the suburban locality the situation is territorially diverse: in the urbanised area there are frequent bus connections (within the town, public communication is free), whereas in the rural commune there are villages with three return connections daily. The coverage of children in childcare is similar to the urban location, but, again, lower in the rural part. In the peripheral locality-Debrznothere is no public transport organised by the municipality. Collective transport and school bussing are provided 
by county public transport and a private company. On average there are 0.3 bus stops per square kilometre and $90 \%$ of villages remain without public transportation on non-school days. Childcare institutions are concentrated in the central town (nursery and kindergarten) with only small pre-primary sections at primary schools in three other villages.

In all three localities there is some form of administrative territorialisation. Sub-municipal units representing city districts or villages in rural areas have at least an advisory role to play, and bring local issues to the municipal agenda. However, their financial resources and discretion are limited. The most developed systemwith district councils - can be found in the urban locality. Territorial thinking can, however, be even more embedded in the principles of municipal management. In its social development policies Gdańsk uses advanced territorialisation. Apart from districts, two other types of entities are taken into consideration in planning. On the one hand there are macro-areas comprising groups of districts used to plan network of ambulatories and schools (synchronised with their zoning); on the other hand, there are neighbourhoods, with 'neighbourhood' defined as an area within a 15-minute walk (bases for planning centres of local activeness, public libraries).

Intra-municipal differentiation is to various degrees reflected in strategic documents and the political agenda. The size and polymorphic character of the municipality makes policy-makers more mindful of the territorial dimension. However, although both intra-municipal differentiation and public services are present in local development strategies, they do not necessarily form one joint objective of social development policy. This transforms the postulated accessibility into availability of services.

\subsection{Empirical Data}

The issue of spatial inequalities in access to public services was investigated as a political postulate, as the ex- perienced status quo and as a field of public intervention. The interviewees assessed their attitudes on a sevenpoint scale, where 1 meant strong disagreement with the statement, and 7 meant strong agreement. In terms of principles, very few respondents were inclined to treat spatial inequalities as a fact of life that-as unavoidablecan be ignored in local polices (see Figure 1). On the contrary, the majority was strongly convinced that spatial inequalities should be actively counteracted. Therefore, we may contend that the normative level spatial exclusion within the municipality is not approved of. However, the accepting of inequalities is most strongly opposed in suburban and urban localities.

But what about the perception of the real situation? Respondents were asked a series of questions probing their perception of (1) the intensity of spatial exclusion with regard to public services, (2) the importance of spatial inequalities as a challenge for the municipality against the background of other problems, (3) the local authorities' engagement in equalising spatial inequalities (Figure 2).

The answers to these three questions provide some interesting results. First, the existence of spatial inequalities in the rural locality is acknowledged far less frequently than could be anticipated judging by the limited offer of public transportation and childcare in the municipality and its territorial concentration in the central town. Second, spatial inequalities are most often emphasised by the respondents from Gdańsk-i.e., the locality with the most extensive public transport and childcare institution network of all locations under scrutiny. Furthermore, the survey respondents are even less inclined to place spatial inequalities among challenges for their municipality than they are to consider them to be substantial. This is especially noteworthy in the case of Debrzno, where the answers suggest that the problem of inequalities is perceived as limited and, furthermore, that there are more important issues the municipality has to deal with. Third, no matter how insignificant the

\section{Spatial inequalities... :}

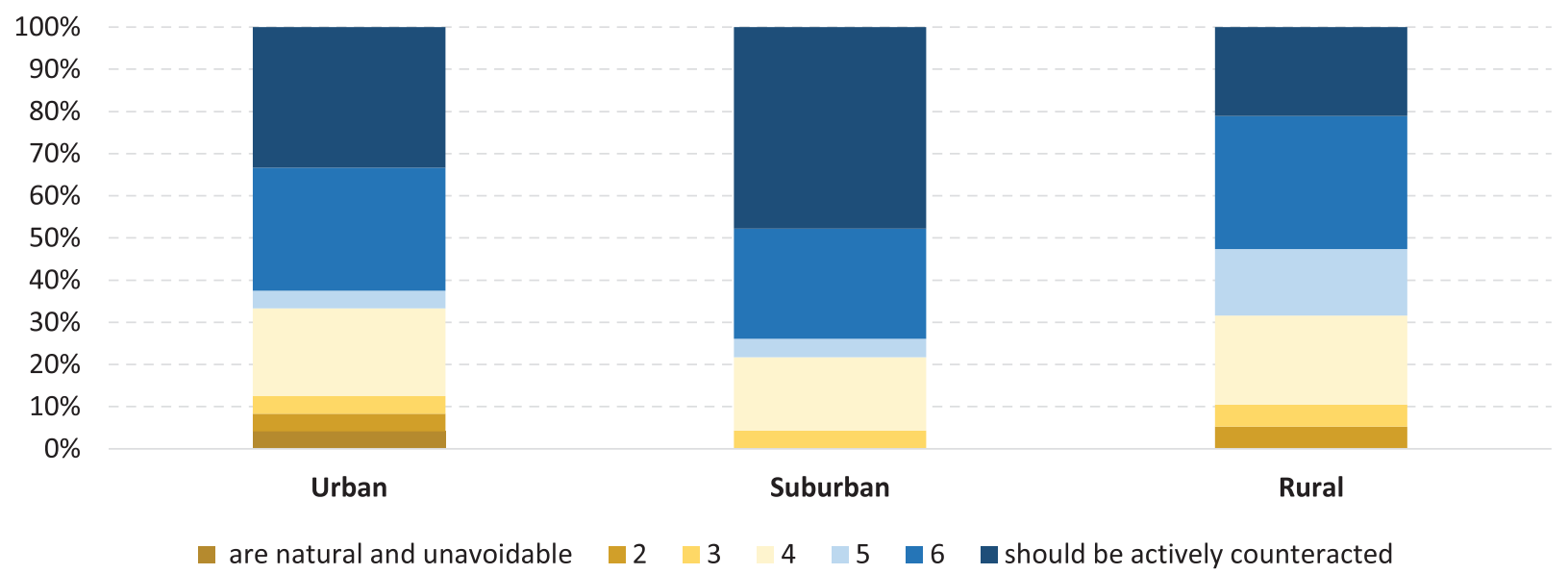

Figure 1. Opinions on spatial inequalities. 
Spatial inequalities in access to public services:

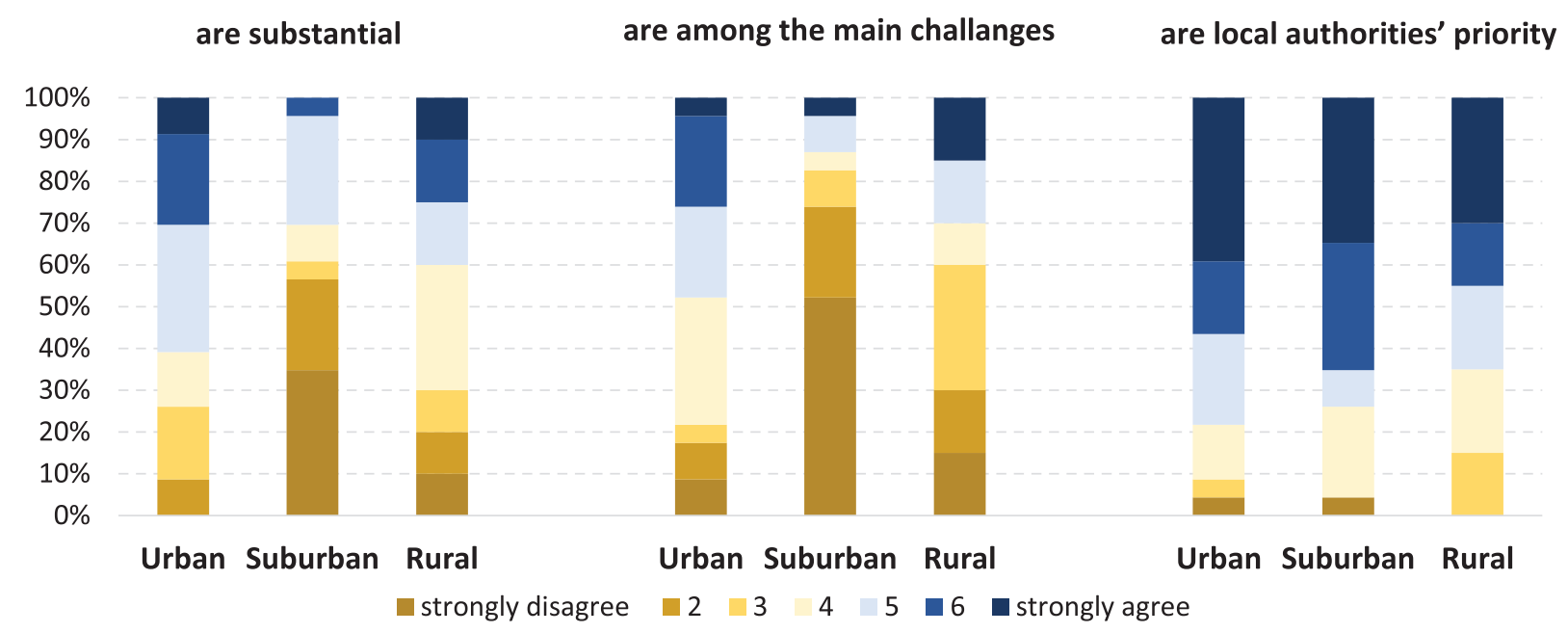

Figure 2. Perception of spatial inequalities at the local level.

inequalities are presented to be, local authorities are considered to be committed to counteracting spatial exclusion. This discrepancy is particularly sizeable in the case of Pruszcz Gdański-a locality in which inequalities are perceived to be almost non-existent but still the authorities' priority.

\section{Discussion}

The results of the survey prove that the perception of spatial inequalities - in both the normative and the empirical sense-is varied in the investigated localities and often defies expectations based on the level of service provision in the municipality. Context factors such as settlement type, level of affluence, and the experiences and expectations of inhabitants and local authorities help understand some unobvious findings.

In Gdańsk, the relatively high level of dissatisfaction with accessibility of public services becomes more understandable if we take into consideration the logic of the city's spatial and social policies on the one hand and the attitudes of residents on the other. Nurturing local communities, planning local centres at the level of neighbourhoods also increases the awareness of local deficiencies in access to SeGls. In some sense it could be viewed as downscaling Magnusson's postulate to "see like a city" (Magnusson, 2010) to an even more granular level. Active, demanding citizens close the feedback loop by putting pressure on local authorities. As framed by a representative of a non-governmental organisation involved in childcare provision in several municipalities in the region:

It's about local awareness. We know that every willing child should have a guaranteed place in a municipal kindergarten, but the average parent who has placed their child in a non-public institution and is not wellinformed can have no clue. It has always been like this, so it's ok. Some local governments take advantage of this....In Gdańsk, especially in some districts, citizens are more aware, and if their children don't get admitted there is a furious row....The city does its job, but such a grass-roots movement provides extra stimulation.

At the other end of the spectrum, Debrzno showcases the pattern of low expectations. The lack of accessible public services has accustomed residents to their absence, converting it into a fact of life-a part of their reality. Many inconveniences have long been responded to with high spirits, internalised beyond recognition, treated like something humorous. As described by one interviewee:

I commuted to work for many years, in summer and in winter, and I managed. There are of course moments when roads are impassable due to snow or snowmelt. Sometimes one might just sit and cry because you don't know what to do: walk across or swim?

\subsection{Community Actor, Rural Locality}

The long-lasting deficiency of public services forced the development of individual strategies to 'make do with what you have' and undermined the significance of spatial inequalities. In many instances, cars filled the gap created by the lack of collective means of transport and remotely situated public care facilities, making a driver licence a must. Some interviewees reflect on the consequences of the lack of public transportation for senior citizens and the unemployed, though the modernisation of the road network is given a higher priority. Secondly, in rural areas the traditional model of family life is more popular than in cities, making maternity leave longer and making the help of relatives in childrearing an alternative to public services. The third factor that weakens the 
attention paid to accessibility of public services is the economic situation of the municipality. The uncertain future of the local labour market and unfavourable demographic trends outscore intra-municipal inequalities on the list of priorities.

Due to its dual nature, the suburban locality combines characteristics present in Gdańsk and Debrzno. The influx of inhabitants from the metropolis made spatial inequalities less acceptable. The newcomers are described as 'demanding' with regard to accessibility and quality of services, relating their expectations to experiences they had in the city. Their pressure is one of the reasons why spatial inequalities are so high on local authorities' priority list. This is especially true in the rural part, where catching up with infrastructure without neglecting any part of a territorially diversified municipality is a part of the political commitment. At the same time, the territorially concise town of Pruszcz Gdański aspires to be a compact city providing high quality of life-thus, driven by slightly different motives, the authorities also feel strongly about accessibility of SeGls. Thanks to its good economic standing, the municipality can quite efficiently deal with the provision of key services to its growing population. This may be why at the general level the disparities are considered of little importance.

We can conclude that the research gives some support for the place-related hypothesis (H1). Indeed, interviewees from the rural locality were least strongly convinced that inequalities should be actively counteracted, and somewhat played down the level of intra-municipal differences in the access to public services. Disapproval of spatial inequalities is stronger in the densely populated urban municipality, and even more so in the subur- ban locality. This brings us to the other hypothesis referring to experiences and expectations $(\mathrm{H} 2)$, which seems to be even better anchored in the data, taking into consideration the contrasting attitudes of respondents from Debrzno versus those from Gdańsk and Pruszcz Gdański.

To summarise, it is important to reflect on the agents that bring about an equalisation of access to SeGls. The survey revealed that almost regardless of the perception of the magnitude of spatial inequalities, local authorities are considered to be committed to counteracting spatial exclusion. Of course, to some extent this can be attributed to the fact that public actors account for half of the sample and indeed assess their own involvement more favourably than other interviewees. On the other hand, there is also evidence supporting the thesis that aspirations of local policy-makers drive the development of public services. In rural, sparsely populated areas the need for more accessible public services is more often expressed by the local authorities, who introduce improved public services without political pressure from the citizens. Table 3 presents some telling statements of community and public actors.

It can be concluded that both bottom-up and topdown impulses can drive the equalisation of spatial disparities at the local level. The former result from the expectations of citizens, while the latter derive from the aspirations of local authorities. Also, the local election process encourages sensitivity to the needs of various groups of voters. Symmetry in investments and equalised development of different parts of the municipality were an explicit political commitment in the suburban locality.

Table 3. Comparison of views on significance of access to public services.

\begin{tabular}{lll}
\hline & Community actors & Public actors \\
\hline Rural locality & “[on public transport in sparsely populated ar- & "Perhaps today Mr Smith doesn't feel a need to \\
& eas] Elderly people prefer to pay a neighbour & use a bus but tomorrow he might. Therefore we \\
& or someone from the family to give them a lift, & fight so that he has access to public transport" \\
& wait for them an hour or two, and drive them & (Local politician).
\end{tabular}

home rather than use public transport, because they would lose a whole day" (Community actor, town).

"[on access to childcare] If someone wants to work, they work. A sister or a granny will take care of their child. There is a woman whose child is slightly disabled. She takes her child to a specialised childcare institution in Człuchów [over $20 \mathrm{~km}$ one-way] by car" (Community actor, village).

Suburban locality "[on public transport in sparsely populated areas] I often wonder why the municipality pays such a lot of money to transport the air" (Community actor, rural part).
“Now we can't imagine our town without a nursery. But at the beginning it was difficult to recruit 10 children. People's attitudes are changing" (Local official).

"We are the only municipality in the county and one of few in the region to organise public transport at such a scale" (Local politician, rural part). 


\section{Conclusion}

Although both hypotheses gain some support in the results of the survey, it is the hypothesis of expectations that seems to better explain the perception and acceptance of intra-municipal inequalities in access to public services. As expected, in the urban context, expectations exceed the current level of provision, whereas in rural areas some inherited, long-lasting forms of territorial exclusion have grown to be considered the norm. 'Settling for less' is often accompanied by an array of individualistic or community-based strategies developed to substitute public services (multiple car ownership, car-pooling, neighbour taxi service, relying on family members for help in child-rearing). However, the inefficiency of such services as public transport in rural areas leaves some vulnerable groups adrift: minors, seniors, the ill and handicapped, and the unemployed. The process of equalising spatial disparities can be driven by both bottom-up and top-down interventions. In the urban environment, public transport is incorporated into the spatial planning vision, while childcare forms part of the social agenda. Grassroots initiatives exert pressure to fix local deficiencies. In suburban localities the approach varies depending on local development strategies and population density. Influxes of urban migrants further increase the pressure to invest in public services. In rural areas, however, the initiative to develop childcare or public transport networks seems to be a top-down vision of social development.

Thus, this study shows the importance of how local stakeholders perceive the role that public services play. We can also conclude that the municipality is an interesting and relevant scale for territorial cohesion. This microlevel is the very one where inequalities are actually experienced and that has the political resources to alleviate spatial disparities or at least bring them to the fore.

of course these place-based interventions are at their best when they are part of a wider, multi-level and cross-sectoral cooperation. The national level plays an important role in hindering the growth of inequality by setting basic standards of public service provision. In 2011 the central government obliged municipalities to make kindergarten available for all willing children. This regulation largely accelerated the achievement of high coverage rates. Nevertheless, as a regulation addressed to municipalities as a whole, it does not guarantee adequate spatial distribution of facilities. Finally, European programmes and funds largely contributed to the development of infrastructure in Poland-including to the provision of SeGls. Furthermore, many EU procedural requirements incentivised public consultations. Even if primarily handled instrumentally, they encouraged more territorial and communitarian practices in local politics.

\section{Acknowledgments}

This article draws on findings from the COHSMO Project, which has received funding from the European Union's
Horizon 2020 Research and Innovation Programme under Grant Agreement No 727058. I would also like to express my gratitude for Professor Paweł Swianiewicz for his encouragement and valuable comments which helped to improve the article.

\section{Conflict of Interests}

The author declares no conflict of interests.

\section{References}

Abrahams, G. (2014). What "is" territorial cohesion? What does it "do"?: Essentialist versus pragmatic approaches to using concepts. European Planning Studies, 22(10), 2134-2155.

Bachtler, J., Martins, J. O., Wostner, P., \& Żuber, P. (2017). Towards cohesion policy 4.0. Structural transformation and inclusive growth. Brussels: RSA Europe.

Barca, F. (2009). An agenda for a reformed cohesion policy: A place-based approach to meeting European Union challenges and expectations. Brussels: DG Regio.

Böhme, K., \& Gløersen, E. (2011). Territorial cohesion storylines: Understanding a policy concept. Heisdorf: Spatial Forsight.

Böhme, K., Doucet, P., Komornicki, T., Zaucha, J., \& Swiatek, D. (2011). How to strengthen the territorial dimension of 'Europe 2020' and the EU cohesion policy: Report based on the Territorial Agenda 2020. Warsaw: Ministry of Regional Development.

Brenner, N. (2009). Open questions on state rescaling. Cambridge Journal of Regions, Economy and Society, 2(1), 123-139.

Castels, M. (1977). Kwestia miejska [The urban question]. Warsaw: Państwowe Wydawnictwo Naukowe.

CEC. (1999). European spatial development perspective: Towards balanced and sustainable development of the territory of the EU. Luxembourg: Office for Official Publications of the European Communities.

CEC. (2008). Green Paper on territorial cohesion. Turning territorial diversity into strength. Luxembourg: Office for Official Publications of the European Communities.

CEC. (2011). White Paper: Roadmap to a single European transport area-Towards a competitive and resource efficient transport system. Luxembourg: Publications Office of the European Union.

Dabinett, G. (2011). Promoting territorial cohesion and understandings of spatial justice. Paper Presented at the Regional Studies and Slovenia Government Office for Local Self-Government and Regional Policy Conference, Bled, Slovenia.

Dao, H., Plagnat Cantoreggi, P., \& Rousseaux, V. (2017). Operationalizing a contested concept: Indicators of territorial cohesion. European Planning Studies, 25(4), 638-660.

Dijkstra, L., Poelman, H., \& Rodríguez-Pose, A. (2020). 
The geography of EU discontent. Regional Studies, 54(6), 737-753.

Domański, H. (2013). Sprawiedliwe nierówności zarobków w odczuciu społecznym [Just income inequality in social perception]. Warsaw: Wydawnictwo Naukowe Scholar.

Doucet, P. (2006). Territorial cohesion of tomorrow: A path to cooperation or competition? European Planning Studies, 14(10), 1473-1485. https://doi.org/ 10.1080/09654310600852449

Duncan, O. D., \& Duncan, B. (1955). Residential distribution and occupational stratification. American Journal of Sociology, 60(5), 493-503.

ESPON. (2007). Study on urban functions (ESPON Project 1.4.3 Final Report). Luxembourg: ESPON.

ESPON. (2013). Indicators of territorial cohesion. Scientific platform and tools project 2013/3/2 (Draft Final Report, Part C). Luxembourg: ESPON \& University of Geneva.

European Commission. (2010). Europe 2020: A strategy for smart, sustainable and inclusive growth. Brussels: Communication from the European Commission.

European Union. (1992). Treaty on European Union, Treaty of Maastricht, (C 325/5). Luxembourg: Office for Official Publications of the European Communities.

Faludi, A. (2004). Territorial cohesion: Old (French) wine in new bottles? Urban Studies, 41(7), 1349-1365.

Glaeser, E. L., Resseger, M., \& Tobio, K. (2009). Inequality in cities. Journal of Regional Science, 49(4), 617-646.

Han, C., Janmaat, J. G., Hoskins, B., \& Green, A. (2012). Perceptions of inequalities: Implications for social cohesion (LLAKES Research Paper 35). London: LLAKES. Retrieved from https://www.llakes. ac.uk/sites/default/files/35.\%20Han\%20Janmaat\% 20Hoskins\%20Green.pdf

Harvey, D. (1973). Social Justice and the city. London: Edward Arnold.

Kaldor, N. (1970). The case for regional policies. Scottish Journal of Political Economy, 17(3), 337-348.

Komornicki, T. (2019). Polska sprawiedliwa komunikacyjnie [Just transport in Poland]. Warsaw: Fundacja im. Stefana Batorego.

Komornicki, T., \& Ciołek, D. (2017). Territorial capital in Poland. In J. Bradley \& J. Zaucha (Eds.), Territorial cohesion: A missing link between economic growth and welfare. Lessons from the Baltic Tiger (pp. 93-146). Gdańsk: Uniwersytet Gdański Katedra Makroekonomii.

Krugman, P. (1991). Increasing returns and economic geography. Journal of Political Economy, 99(3), 483-499.

Levitas, T., \& Herczyński, J. (2002). Decentralization, local governments and education reform in Poland. In K. Davey (Ed.), Balancing national and local responsibilities: Education management and finance in four central European countries (pp. 91-113). Budapest: LGI.
Magnusson, W. (2010). Seeing like a city. In J. Davies \& D. Imbroscio (Eds.), Critical urban studies: New directions (pp. 41-53). Albany, NY: State University of New York Press.

Markusen, A. (1999). Fuzzy concepts, scanty evidence, policy distance: The case for rigour and policy relevance in critical regional studies. Regional Studies, 33(9), 869-884.

Medeiros, E. (2016). Territorial cohesion: An EU concept. European Journal of Spatial Development, 1(60), 1-30.

Mirwaldt, K., Mcmaster, I., \& Bachtler, J. (2009). Reconsidering cohesion policy: The contested debate on territorial cohesion (European Policies Research Paper No. 66). Glasgow: European Policies Research Centre, University of Strathclyde.

Morel, N., Palier, B., \& Palme, J. (2012). Towards a social investment welfare state? Ideas policies and challenges. Bristol: Policy Press.

Musterd, S., Tammaru, T., van Ham, M., \& Marcińczak, S. (2016). Inequality and rising levels of socio-economic segregation: Lessons from a pan-European study. In T. Tammaru, M. van Ham, S. Marcińczak, \& S. Musterd (Eds.), Socio-economic segregation in European capital cities: East meets West (358-382). London: Routledge.

Myrdal, G. (1957). Economic theory and under-developed regions. London: Duckworth.

OECD. (2018a). Divided cities. Understanding intra-urban inequalities. Paris: OECD.

OECD. (2018b). Inclusive growth and social cohesion in cities: An OECD approach.Paris: OECD.

OECD. (2019). OECD regional outlook 2019. Paris: OECD.

Servillo, L. (2010). Territorial cohesion discourses: Hegemonic strategic concepts in European spatial planning. Planning Theory and Practice, 11(3), 397-416.

Servillo, L., Atkinson, R., \& Russo, A. P. (2012). Territorial attractiveness in EU urban and spatial policy: A critical review and future research agenda. European Urban and Regional Studies, 19(4), 349-365.

Śleszyński, P. (2013). Delimitacja miejskich obszarów funkcjonalnych stolic województw [Delimitation of the Functional Urban Areas around Poland's voivodship capital cities]. Przegladd Geograficzny, 85(2), 173-197.

Śleszyński, P., \& Komornicki, T. (2016). Klasyfikacja funkcjonalna gmin polski na potrzeby monitoringu planowania przestrzennego [Functional classification of Poland's communes (gminas) for the needs of the monitoring of spatial planning]. Przeglqd Geograficzny, 88(4), 469-488.

Stanny, M., Rosner, A., \& Komorowski, Ł. (2018). Monitoring Rozwoju Obszarów Wiejskich Etap III. Struktury społeczno-gospodarcze, ich przestrzenne zróżnicowanie i dynamika [Rural development monitoring. Stage III. Socio-economic structures, their spatial differenciation and dynamics]. Warsaw: Fundacja Eu- 
ropejski Fundusz Rozwoju Wsi Polskiej Instytut Rozwoju Wsi i Rolnictwa PAN.

Świątek, D., Czapiewski, K., \& Komornicki, T. (2013). Services of general interests in Mazowsze region: Abbreviation of ESPON SeGI case study report. Europa XXI, 23, 149-176.

Swyngedouw, E. (2005). Governance innovation and the citizen: The Janus face of governance-beyond-thestate. Urban Studies, 42(11), 1991-2006.

Thirlwall, A. P. (2014). Kaldor's 1970 regional growth model revisited. Scottish Journal of Political Economy, 61(4), 341-347.

Treaty of Amsterdam amending the Treaty on European Union, the Treaties establishing the European Communities and certain related acts, 97/C 340/01 (1997).

\section{About the Author}

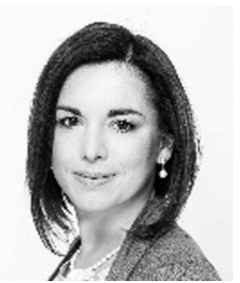

Wirginia Aksztejn (MA in Sociology) is a Research Assistant in the Department of Local Development and Policy and a PhD student in Doctoral School of Social Sciences at the University of Warsaw, Poland. She has been involved in social and marketing research since 2005. Her current research focuses on local government studies, in particular on local economic development, spatial inequalities and cohesion policies.
Treaty of Lisbon amending the Treaty on European Union and the Treaty establishing the European Community, 2007/C 306/01 (2007).

Turner, B. (1986). Equality. London: Ellis Horwood.

van Kempen, R., \& Murie, A. (2009). The new divided city: Changing patterns in European cities. Tijdschrift Voor Economische En Sociale Geografie, 100(4), 377-398.

van Well, L. (2012). Conceptualizing the logics of territorial cohesion. European Planning Studies, 20(9), 1549-1567.

Venkatesh, V., Brown, S. A., \& Sullivan, Y. W. (2016). Guidelines for conducting mixed-methods research: An extension and illustration. Journal of the Association for Information Systems, 17(7), 435-495. 